\title{
Late Malignancy after 26 Years of Evolution on an Untreated Perianal Fistula
}

\author{
Lucian Sorin ANDREI ${ }^{1,2}$, Adriana Corina ANDREI ${ }^{1,2}$, Alexandru MICU², Radu Sorin POPISTEANU², \\ Mona DUMBRAVA²
}

\begin{abstract}
Squamous cell carcinoma and basal cell carcinoma are two types of neoplasms that rarely affect the perianal region, and their etiology is still a matter for debate. We present the case of a 75 year old patient with a 26 year history of perianal fistula, who presents with purulent and fecal perianal discharge and swelling at this level. Physical examination and anoscopy detected low transsphincteric fistula. The biopsy revealed the diagnosis of squamous cell carcinoma, for which a local excision was performed followed by adjuvant radiotherapy. Two years after this event, the patient presented with another perianal lession, which according to the histopathological result was a basal cell carcinoma; local excision was the only treatment performed for this malignancy.
\end{abstract}

Keywords: perianal, fistula, fistulotomy, squamous, basal, carcinoma.

\section{Rezumat}

Carcinomul scuamos și carcinomul bazocelular reprezintă două tipuri de neoplazii care afectează foarte rar regiunea perianală, iar etiologia lor este încă în dezbatere. Prezentăm cazul unui pacient în vârstă de 75 ani, cu istoric de 26 de ani de fistulă perianală, care se prezintă pentru scurgeri perianale purulente și fecaloide și tumefacție la acest nivel. Examenul fizic și explorarea anoscopică a decelat o fistulă transsfincteriană joasă. Biopsia relevă carcinom scuamos, pentru care s-a efectuat excizie locală urmată de radioterapie adjuvantă. La 2 ani de la acest eveniment pacientul se prezintă cu altă formațiune tumorală perianală, care în urma rezultatului histopatologic se constată a fi carcinom bazocelular; excizia locală a reprezentat tratamentul unic pentru cea de-a doua neoplazie.

Cuvinte cheie: perianal, fistula, fistulotomie, scuamos, bazal, carcinom.

\section{INTRODUCTION}

Anal and perianal tumors represent a rare pathology, and the presentation can vary greatly given the complex anatomy of this region. The most common form of cancer at this level is squamous cell carcinoma, the frequency at the perianal level being three to five times lower than at the anal canal level ${ }^{1}$. Perianal squamous cell carcinoma, unlike anal canal carcinoma, is staged and treated like any other squamous cell carcinoma of the skin ${ }^{2}$. Inspite of being the most common neoplasm

${ }^{1}$ Mediproct Clinic, Bucharest, Romania

${ }^{2}$ Fundeni National Institute, Bucharest, Romania of the skin, basal cell carcinoma with perianal localisation is extremely rare.

\section{CASE PRESENTATION}

We present the case of a 75 year-old patient, with long history of perianal fistula for which he did not receive specific treatment, who presents at our clinic for purulent and fecal perianal discharge and a small swelling at 9 o'clock left lateral decubitus. The associated pathologies of this pacient are essential hypertension, prostate

Corresponding author:

Lucian Sorin ANDREI, Fundeni National Institute, 158 Fundeni Avenue, $2^{\text {nd }}$ District, Bucharest Romania.

E-mail: sandrei741@gmail.com 
adenoma diagnosed in 2008, and hemorrhoidal disease for which hemorroid banding was performed in 2008.

Clinical and anoscopic examination reveals low transspincteric perianal fistula and grade II hemorrhoids. The other paraclinical exams and colonoscopy were normal. The patient tested negative for HPV infection. Fistulotomy was performed and a partially epithelialized fistulous tract with an ulceration area were discovered. A biopsy from the the ulceration was performed and revealed a well differentiated, keratinized exulcerated squamous cell carcinoma. After the diagnosis, a CT examination was performed which did not show the presence of metastasis. Shortly after the biopsy, the excision of the perianal lesion was performed, and the initial diagnosis of SCC on the perianal fistula was confirmed. Following the excision, the patient underwent adjuvant radiotherapy treatment as recommended by the oncologist. During the adjuvant treatment the patient presented with abdominal bloating and diarrheal stools (10 stools/day) with onset approximately 3 weeks after the initiation of radiotherapy. This manifestations were suggestive for severe root enteritis, which is why radiotherapy treatment was stopped. Subsequently the evolution was favorable and without complications.

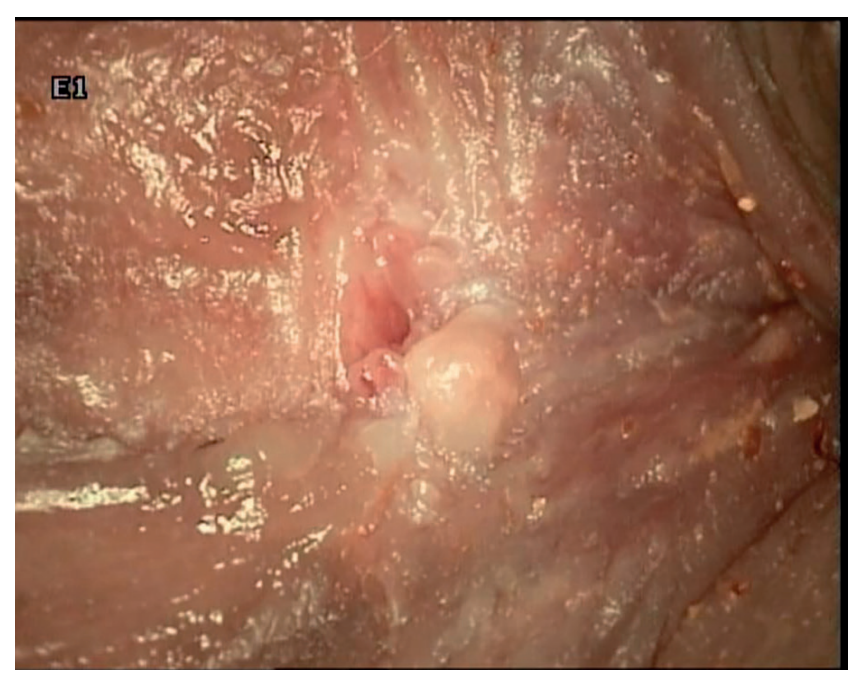

Figure 1. Squamous cell carcinoma on fistulous tract

The patient was monitored periodically, and two years after the initial operation, a $15 / 7 \mathrm{~mm}$ tumor at 7 o'clock left lateral decubitus is discovered. A complete resection of the tumor is performed, and the histopathological result of the resected specimen reveals basal cell carcinoma, with nodular shape, with lateral and deep margins of resection free of tumor tissue.

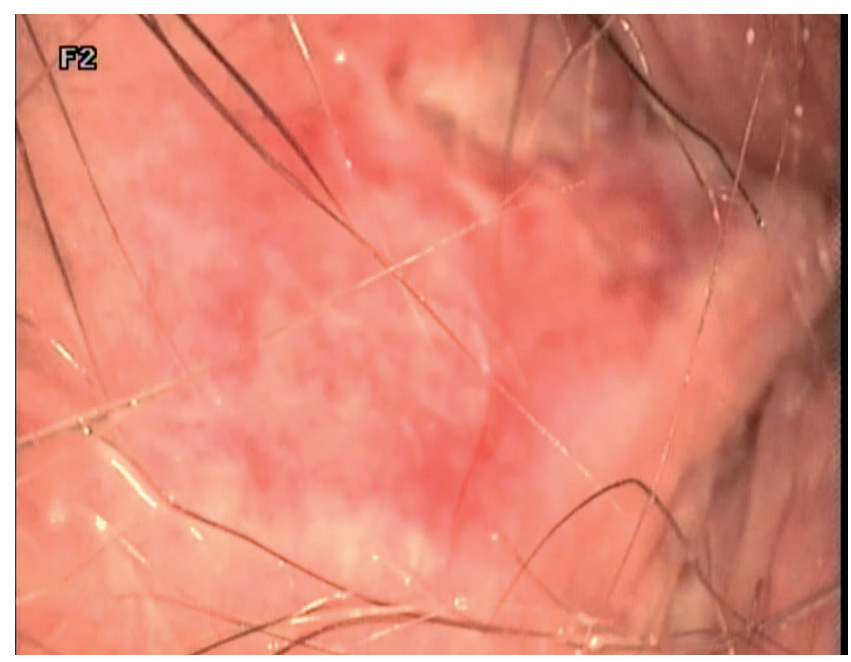

Figure 2. Perianal basal cell carcinoma

Postoperative follow-up was performed by clinical and MRI examinations, which showed no tumoral presence 5 years after surgery.

\section{DISCUSSIONS}

A strong link has been discovered between anal squamous cell carcinoma and HPV infection ( especialy type 16 and 18), this aspect also being shared with cervical cancer ${ }^{3}$. Aditional risk factors are smoking, anal sex, HIV infection and $\mathrm{AIDS}^{4}$. In our case, the pacient hasn't recalled any of the above mentioned practices, and has been tested negative for HPV.

The posibility of anal cancer being associated with fissures, fistulas, perianal abcesses and hemorhoids is still under debate. Some authors suggest that irritation, long term inflammation and repeted epitelial regrowth generated by these conditions are contributing factors to cancer development ${ }^{5,6}$; on the other hand case control type studies stated that the association is minimal or nonexistant ${ }^{7}$. Chronic fistulas can represent a site of implantation for colo-rectal cancer or endometriosis ${ }^{8,9}$. Given the pacients history of over 26 years of perianal fistula, without the rest of his underlining conditions bearing any significance regarding his perianal and anal pathology,a cause-efect relationship is hipothesised between his long term perianal and anal condition, and his more recently developed cancer.

Local tumor resection is the elective treatment in 60-70\% of anal verge squamous cell carcinoma cases, 
while abdomino-perineal resection si reserved for the advanced cases $^{10,11}$. Moderate and high differentiated carcinomas with a maximum diametre of $<2 \mathrm{~cm}$, without limph node dissemination and without the involvment of the anal sphincter benefit from local excision ${ }^{12,13}$. Given the reduced size and superficial localisation of the tumor in our case, tumor resection was performed followed by adjuvant radiotherapy treatment.

Basocelular carcinoma is the most common skin tumor, it's main cause beeing UV radiation exposure ${ }^{14}$. Genital and perianal areas are affected in less than $1 \%$ of the cases, while the most common localisation of this neoplasic pathology $(>80 \%)$ is on the most exposed areas to sunlight ${ }^{15}$. The perianal basal cell carcinoma found in our case appeared two years after the first cancer; taking into account the patient's history of radiotherapy for his first cancer and also the important timeframe between the irradiation and cancer onset it is safe to assume that radiotherapy is a probable cause. Since this tumor type is non-agresive we considered local excision as the best therapeutic option.

\section{References}

1. Balamucki CJ, Zlotecki RA, Rout WR, Newlin HE, Morris CG, Kirwan JM, George TJJr, Mendenhall WM. Squamous cell carcinoma of the anal margin: the university of Florida experience. Am J Clin Oncol. 2011 Aug;34(4):406-10.

2. Leonard D, Beddy D, Dozois EJ. Neoplasms of anal canal and perianal skin. Clin Colon Rectal Surg. 2011 Mar;24(1):54-63.

3. Gami B, Kubba F, Ziprin P. Human papilloma virus and squamous cell carcinoma of the anus. Clin Med Insights Oncol. 2014 Sep 17;8:113-9.

4. Chawla AK, Willett CG. Squamous cell carcinoma of the anal canal and anal margin. Hematol Oncol Clin North Am. 2001 Apr;15(2):321-44

5. Nordenvall C, Nyrén O, Ye W. Elevated anal squamous cell carcinoma risk associated with benign inflammatory anal lesions. Gut. 2006 May;55(5):703-7.

6. Tomoko S, Noritake T, Seiichi Shinji. Squamous cell carcinoma arising from reccurent anal fistula. J Nippon Sch 2007; 74(4)

7. Gervasoni JE Jr, Wanebo HJ. Cancers of the anal canal and anal margin. Cancer Invest. 2003 Jun;21(3):452-64.

8. Andrei I., Popisteanu S.T., Andrei A. Rare case of perianal endometriosis complicted with perinal fistula: case report. Modern medicine 2019 Jun; 26(2), 89-91.

9. Andrei L., Andrei A., Popisteanu S.R. Adenocarcinoma Developing at the Level of a Chronic Perianal Fistula by Cell Implantation from a Proximal Rectal Cancer. Modern medicine 2020 Jun; 27(2), 133-138

\section{CONCLUSIONS}

Perianal fistula with prolonged evolution can present itself as a risk factor for malignant lesions at this level, which is why treatment of the fistula alone is not enough when the fistulous tracts present modifications. The recommended approach involves multiple biopsies from fistulous tracts plus biopsies targeting suspicious lesions followed by histopathological examination; repeated clinical and imaging evaluations also bear great importance.

Compliance with ethics requirements: The authors declare no conflict of interest regarding this article. The authors declare that all the procedures and experiments of this study respect the ethical standards in the Helsinki Declaration of 1975 , as revised in 2008(5), as well as the national law. Informed consent was obtained from all the patients included in the study.

10. Abboud B, Ingea H, Tayar C, Abadjian G. Epidermoid carcinoma developing in a chronic anal fistula. Presse Med. $2000 \mathrm{Apr}$ 15;29(14):786-7.

11. Göttgens KW, Janssen PT, Heemskerk J, van Dielen FM, Konsten JL, Lettinga T, Hoofwijk AG, Belgers HJ, Stassen LP, Breukink SO. Long-term outcome of low perianal fistulas treated by fistulotomy: a multicenter study. Int J Colorectal Dis. 2015 Feb;30(2):213-9.

12. Glynne-Jones R, Northover JM, Cervantes A; ESMO Guidelines Working Group. Anal cancer: ESMO Clinical Practice Guidelines for diagnosis, treatment and follow-up. Ann Oncol. 2010 May;21 Suppl 5:v87-92.

13. Chandramohan K, Mathew AP, Muralee M, Anila KR, Ramachandran K, Ahamed I. Squamous cell carcinoma arising from long-standing perianal fistula. Int Wound J. 2010 Dec;7(6):5158.

14. D V Nagendra Naidu, V Rajakumar. Perianal basal cell carcinoma-an unusual site of occurence Indian J Dermatol. 2010 AprJun; 55(2): 178-180.

15. Gibson GE, Ahmed I. Perianal and genital basal cell carcinoma: An clinicopathologic review of 51 cases. J Am Acad Dermatol. 2001 Jul;45(1):68-71. 